\title{
NOVEL APPROACH FOR COLLECTING MICROALGAE IN WATER TREATMENT USING MAGNETIC NANOCOMPOSITES BASED ON BIOPOLYMER EXTRACTED FROM GRAPEFRUIT PEEL
}

\author{
NGHIA T. BUI ${ }^{1}$, LOAN T. B. DUONG $^{2}$, LAN HUONG NGUYEN $^{3}$, NGOC T. T. TRAN $^{4}$ \\ ${ }^{1}$ Institute of Environmental Science, Engineering and Management, Industrial University of Ho Chi Minh \\ City, Ho Chi Minh City, Vietnam, \\ ${ }^{2}$ Petrovietnam Camau Fertilizer Joint Stock Company, Ca Mau Province, Viet Nam, \\ ${ }^{3}$ Faculty of Environment - Natural Resources and Climate Change, Ho Chi Minh City University of \\ Food Industry (HUFI), \\ ${ }^{4}$ Ho Chi Minh City University of Natural Resources and Environment, Ho Chi Minh City, Vietnam. \\ btnghia109@gmail.com,ngoc.tran1011@gmail.com
}

\begin{abstract}
In this work, magnetic nanocomposites were produced by incorporating cobalt superparamagnetic $(\mathrm{CoFe} 2 \mathrm{O} 4)$ nanoparticles into the biopolymer matrix which was extracted from grapefruit peel. In which, the magnetic nanoparticles were prepared by co-precipitation approach and the nanocomposite formation was carried out with the support of ultrasonic waves. The obtained biopolymer, nanoparticles and nanocomposites were characterized by Fourier transform infrared (FT-IR) while nanoparticles and nanocomposites were further characterized by X-ray powder diffraction (XRD), scanning electron microscopy (SEM) and vibrating sample magnetometry (VSM). Finally, the capability to collect the Tetraselmis sp. microalgae using the achieved superparamagnetic nanocomposites was assessed and effects of various factors including material weight, stirring speed and stirring time on the recovery yield were also investigated. It was found that a recovery yield of higher than $90 \%$ was attained when using the nanocomposites at the concentration of $4 \mathrm{~g} / \mathrm{L}$. In addtition, the highest efficiency was reached in the case the coagulation was done by stirring at $200 \mathrm{rpm}$ for 3 mins and the flocculation was performed by slow stirring at $50 \mathrm{rpm}$ for 2 mins.
\end{abstract}

Keywords. nanocomposites, magnetic, grapefruit, biopolymer, microalgae.

\section{INTRODUCTION}

Recently, together with the rapid industrialization, climate change causes a serious shortage of water resources in many regions all over the world, especially in Southeast Asia countries including Vietnam. Apart from saving water or exploiting other water sources, treating and recycling the wastewater is one of the solutions for overcoming the water crisis. Water treatment can be done via different methods with their own advantages and disadvantages [1]. Among them, microalgae-based treatment, an emerging environmentally friendly technology, has been considered a potential method to improve the quality of water [2]. Particularly, microalgae absorb the nutrients in wastewater and convert them into biomass. In addition, the collected biomass can be used as animal feed, fertilizer or alternative energy source for biodiesel production. However, efficient microalgae harvesting is still a challenge to make the method best choice. Up-to-date, the microalgae harvesting is being done simply by sedimentation which takes time and inconvenient in collecting the biomass. Therefore, finding a new efficient technique to recover the microalgae after wastewater treatment is essential.

Among various types of nanoparticles, magnetic nanoparticles, due to their interesting magnetic properties, have gained significant attention and been investigated for a wide range of application, namely catalysis, magnetic fluids, imaging, data storage and especially environmental remediation [3]. However, these magnetic nanoparticles, owing to their supermagnetic interaction, tend to aggregate easily when 
being dispersed in the working media which may hinder the particles from executing their application. To solve this problem, considerable efforts have been carried out trying to incorporate the magnetic nanoparticles into a matrix which can be polymer, ceramic or even metal depending on the application forming nanocomposites [4]. Of all the matrix types, polymer nanocomposites offer significant potential for numerous applications. In which, biopolymer is becoming a first priority due to their biodegradable properties.

Grapefruit is a popular fruit tree in Vietnam with a huge annual consumption quantity. However, only $50 \%$ of fresh weight of its fruit is edible and the rest $50 \%$, mainly the grapefruit peel, is waste and discarded into the environment. With millions of tons of grapefruit consumed each year, the waste grapefruit peel would be an extensive amount meanwhile they can provide an abundant source for biopolymers.

In this study, a biopolymer-based magnetic nanocomposite was prepared by incorporating cobalt superparamagnetic $\left(\mathrm{CoFe}_{2} \mathrm{O}_{4}\right)$ nanoparticles into a biopolymer matrix extracted from waste grapefruit peel. The obtained material was used for collecting Tetraselmis sp., a fast-growing green algal genus of phytoplankton which is rich in lipid content and very useful for not only research but also industry.

\section{MATERIALS AND METHODS}

\subsection{Materials}

The reagents including cobalt (II) chloride $\left(\mathrm{CoCl}_{2} \cdot 6 \mathrm{H}_{2} \mathrm{O}, 99 \%\right)$; Iron (II) chloride $\left(\mathrm{FeCl}_{2} \cdot 4 \mathrm{H}_{2} \mathrm{O}, 98 \%\right)$; sodium hydroxide $(\mathrm{NaOH}, 96 \%)$; n-hexane $(95 \%)$; ethanol $\left(\mathrm{C}_{2} \mathrm{H}_{5} \mathrm{OH}, 99.7 \%\right)$ and ammonium hydroxide $\left(\mathrm{NH}_{4} \mathrm{OH}, 25-28 \%\right)$ were obtained from Xilong Chemical (China) while sodium dodecyl sulfate (SDS, >80\%) was provided by Acros. All the reagents were used as received without any further purification. The grapefruit (Citrus x parradisi) peel was collected from Go Vap market, Go Vap district, HCM city, Vietnam whereas microalgae Tetraselmis sp. was provided by Institute for Environmental Science, Engineering and Management (IESEM), Industrial University of Ho Chi Minh City (IUH), on April 3, 2017.

\subsection{Biopolymer isolation}

Firstly, grapefruit peel was washed and removed the green peel to keep the white pulp. The white pulp was then cut into small pieces and blanched in hot water $\left(50{ }^{\circ} \mathrm{C}\right)$ in order to discard the left glucose as well as increase the contact area between material and solvent. The as-blanched white pulp was dried to constant mass at $60{ }^{\circ} \mathrm{C} .10 \mathrm{~g}$ of dried pulp was hydrolyzed in citric acid for certain time at the required temperature. The solution was filtered to collect the filtrate and ethanol precipitation was performed to obtain the biopolymer. Finally, the achieved biopolymer was dried at $50{ }^{\circ} \mathrm{C}$ prior to storage [5].

\subsection{Formation of magnetic nanoparticles}

The preparation of $\mathrm{CoFe}_{2} \mathrm{O}_{4}$ magnetic nanoparticles were done following a known procedure of coprecipitation using sodium dodecyl sulfate (SDS) as surfactant. Briefly, $250 \mathrm{ml}$ aqueous solution of SDS (9.35 g; $27.75 \mathrm{mmol}$ ) was instantly added into $250 \mathrm{ml}$ aqueous solution of a mixture containing $\mathrm{CoCl}_{2} \cdot 6 \mathrm{H}_{2} \mathrm{O}(1.2 \mathrm{~g} ; 5 \mathrm{mmol})$ and $\mathrm{FeCl}_{2} \cdot 4 \mathrm{H}_{2} \mathrm{O}(2 \mathrm{~g} ; 10 \mathrm{mmol})$. The mixture was stirred for $30 \mathrm{mins}$ and heated to $\left(70 \pm 5{ }^{\circ} \mathrm{C}\right)$. Then, $500 \mathrm{ml}$ of $0.75 \mathrm{M} \mathrm{NaOH}$ was gradually poured into the reaction vessel. The formed magnetic nanoparticles were collected after vigorous stirring for 5 hours by a strong magnet, washed with water, ethanol and n-hexane to remove the excess of surfactant. Finally, the precipitates were left for drying overnight in air, at room temperature [6].

\subsection{Hydroxylation of magnetic nanoparticles}

$\mathrm{CoFe}_{2} \mathrm{O}_{4}$ magnetic nanoparticles were dispersed in $350 \mathrm{ml}$ mixture of ethanol and water with the volume ratio of $1: 1$ in the aid of ultrasonic wave for 30 mins. Then, $35 \mathrm{ml}$ ammonium hydroxide was added and the suspension was vigorously stirred at $55 \div 65{ }^{\circ} \mathrm{C}$ in 24 hours. Hydroxylated magnetic nanoparticles were collected by a strong magnet, washed with excess of water, ethanol and left for drying 
overnight in air, at room temperature [6].

\subsection{Formation of nanocomposites}

Solutions of biopolymer and hydroxylated magnetic nanoparticles with certain ratio were added into a beaker and ultrasonicated for a period of time. The formed nanocomposites were taken out using a strong magnet, washed with excess of water, ethanol and left for drying in air.

\subsection{Characterization}

Infrared spectra in the range of $400-4000 \mathrm{~cm}^{-1}$ were measured by Fourier transform infrared (FT-IR) spectrometer (TENSOR 27- Bruker, Germany) while X-ray diffraction (XRD) patterns were recorded by a D8-Advance from Bruker using monochromatic $\mathrm{Cu} \mathrm{K}_{\alpha}$ radiation to study the structure of the materials. The $2 \theta$ scanning ranges from $10-80^{\circ}$ at a scanning rate of $2.25^{\circ} / \mathrm{min}$. Morphology of the nanomaterials was observed by Scanning Electron Microscopy (SEM) with S-4800, Hitachi and magnetic properties was assessed via hystereris loop which was achieved using a vibrating sample magnetometer (VSM).

\subsection{Microalgae recovery}

Firstly, $50 \mathrm{ml}$ solution of algae Tetraselmis sp. with the concentration of around 5 million cells per $\mathrm{mL}$ was put into a beaker. Then, a certain amount of materials, either magnetic nanoparticles or nanocomposites, was added. The mixture was stirred at $200 \mathrm{rpm}$ for 3 mins and then $50 \mathrm{rpm}$ for 2 mins. The deposition was assisted with a magnet and the left amount of algae in the solution was determined. The recovery efficiency was calculated as follows [7]:

$$
\operatorname{Yield}(\%)=\left(1-\frac{C_{t}}{C_{o}}\right) * 100 \%
$$

where $\mathrm{C}_{\mathrm{t}}$ is the microalgal biomass in the medium after harvesting and $\mathrm{C}_{\mathrm{o}}$ is the initial biomass in the culture medium.

\section{RESULTS}

\subsection{Effect of processing parameters to biopolymer isolation from grapefruit peel}

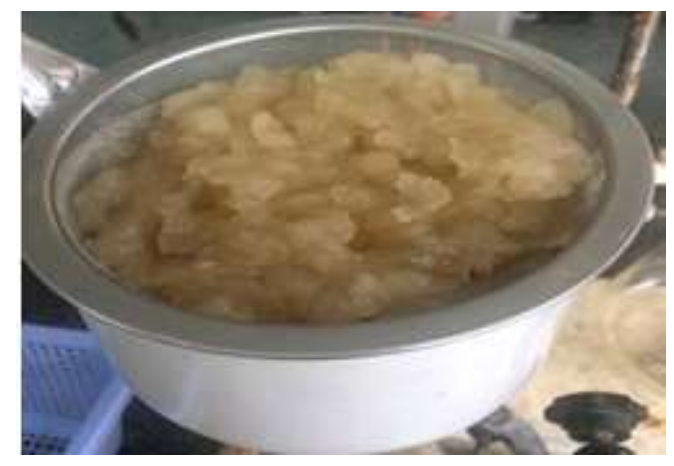

Figure 0.1. Biopolymer isolated from grapefruit peel

A fixed amount of $10.0 \mathrm{~g}$ grapefruit peel was used for biopolymer isolation. According to previous studies [8-10], it was reported that the enzyme-reduction is not completed at the temperature below $60{ }^{\circ} \mathrm{C}$ while at the temperature higher than $100{ }^{\circ} \mathrm{C}$, the plant samples would be swell and become gel which cause difficulties in followed stages. Therefore, the proper temperature for enzyme reduction was investigated. Apart from temperature, biopolymer isolation of plants also depends on various parameters or conditions including: sample/solvent ratio, concentration of enzyme-reducing agent, isolation time [8, $10-14]$. 
NOVEL APPROACH FOR COLLECTING MICROALGAE IN WATER TREATMENT USING
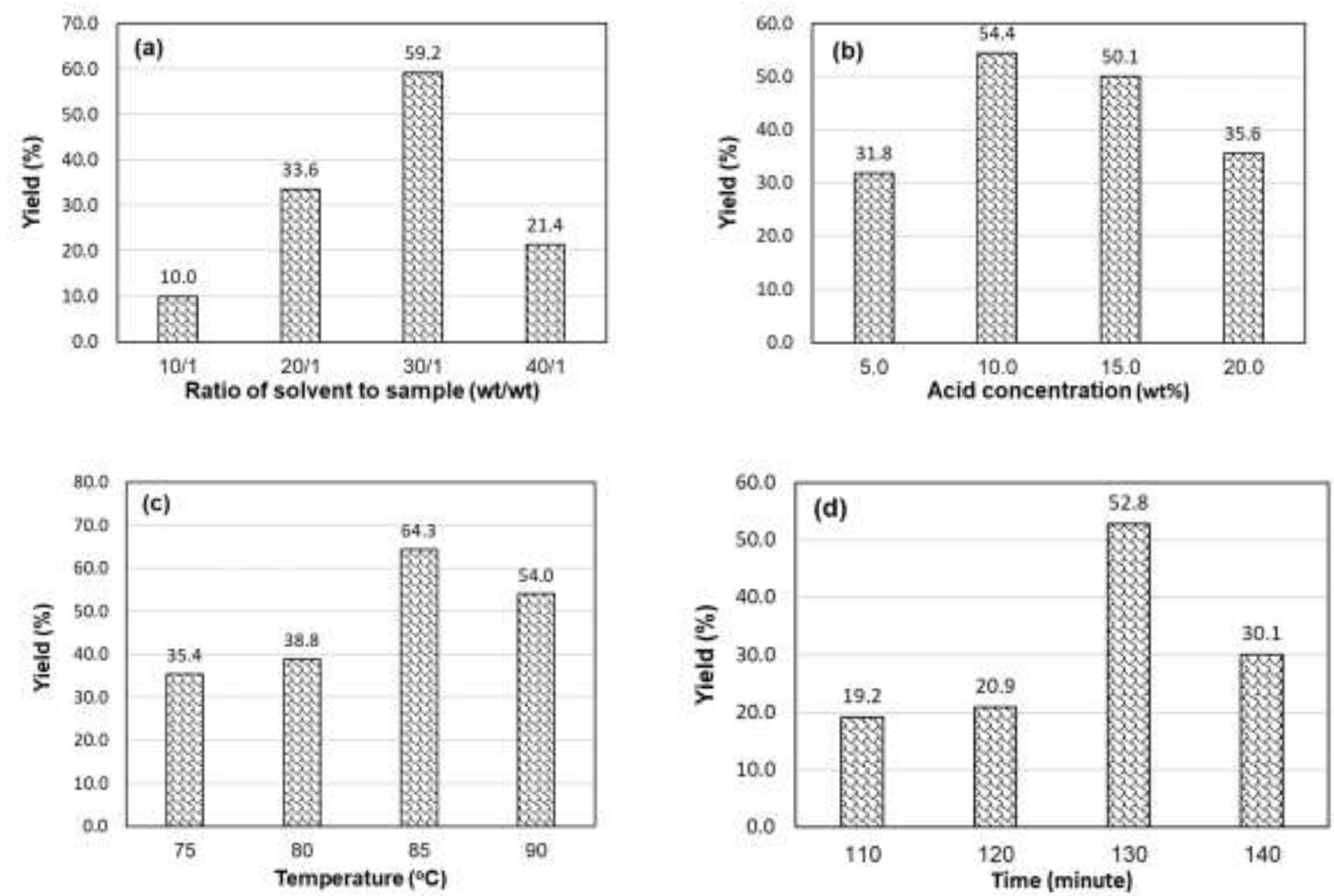

Figure 0.2. Effect of ratio of solvent to sample $(10 / 1 \div 40 / 1)$ (a); acid citric concentration $(5 \div 20 \mathrm{wt} \%)$ (b); temperature $(75 \div 90 \mathrm{oC})(\mathrm{c})$ and time $(110 \div 140 \mathrm{mins})(\mathrm{d})$ to biopolymer isolation from grapefruit peel

Results of investigating the effect of biopolymer isolation conditions show that the maximum amount of biopolymer was obtained when the mass ratio of solvent/grapefruit peel sample reached 30/1 (wt/wt). The yield of biopolymer isolation was lower when either increasing or reducing this weight ratio (Figure 3.2 a). These results might be due to the fact that the amount of solvent is not sufficient for the swelling of the grapefruit peel causing difficulties for acid citric to perform the enzyme reduction when decreasing the ratio of solvent to sample. On the other hand, increasing the mass ratio of solvent to sample might lead to the increasement of $\mathrm{H}^{+}$ions in the solution (with a constant used amount of $10 \mathrm{wt} \%$ citric acid) which improves the solubility of biopolymer $[10,12,14]$. The highest yield of biopolymer isolation achieved when the concentration of citric acid is $10 \mathrm{wt} \%$ was $54.4 \%$ (Figure $3.2 \mathrm{~b}$ ). Increasing further the concentration of citric acid to higher than $10 \mathrm{wt} \%$ resulted in a stronger acidic condition. This leads to a higher solubility of biopolymer in aqueous solution, hence the recovery capability of biopolymer decreased. On the other hand, decreasing the citric acid concentration caused a deduction in acidity of the media leading to the enzyme reducing capability, then reducing the transforming ability of $-\mathrm{COOCH}_{3}$ group with weak polarity into - $\mathrm{COOH}$ form with stronger polarity. As a result, the obtained amount of biopolymer reduced. This is in accordance with the results reported in previous studies [13-15]. The effect of temperature was also studied in this work in which the highest biopolymer isolation yield of $64.3 \%$ was achieved at $85{ }^{\circ} \mathrm{C}$ (Figure $3.2 \mathrm{c}$ ). This finding was also reported in previous research [10-13]. In addition, obtained biopolymer amount depends on the isolation time where $52.8 \%$ was the highest yield when carrying out the isolation for 130 mins and prolong the time lead to the decrease of isolation yield (Figure $3.2 \mathrm{~d}$ ). It was reported in other studies that the time for biopolymer isolation depends on several factors including types of plant, moisture, type of solvent and temperature [5, 8, 10, 12-16].

\subsection{Synthesis of magnetic nanomaterials}

$\mathrm{CoFe}_{2} \mathrm{O}_{4}$ magnetic nanoparticles were synthesized following a known coprecipitation approach in the presence of the surfactant SDS $[6,17]$. The structure of prepared magnetic nanoparticles was investigated 
by X-ray Diffraction (XRD). Results (Figure 3.3) show that the diffraction pattern of the nanoparticles totally matches with the standard one (JCPDS card, No. 22-1086) confirming the 'cubic spinel' structure of obtained $\mathrm{CoFe}_{2} \mathrm{O}_{4}$ nanoparticles. This result is also in a good accordance with the previously reported findings on $\mathrm{CoFe}_{2} \mathrm{O}_{4}$ magnetic nanoparticles[17-20]. It is noted that there is an absence of the peaks which represent impurities and amorphous structures in XRD result. In addition, it is observed in SEM image (Figure 3.4) that the diameter of the $\mathrm{CoFe}_{2} \mathrm{O}_{4}$ magnetic nanoparticles varies in the range of $30 \div 40$ nm.

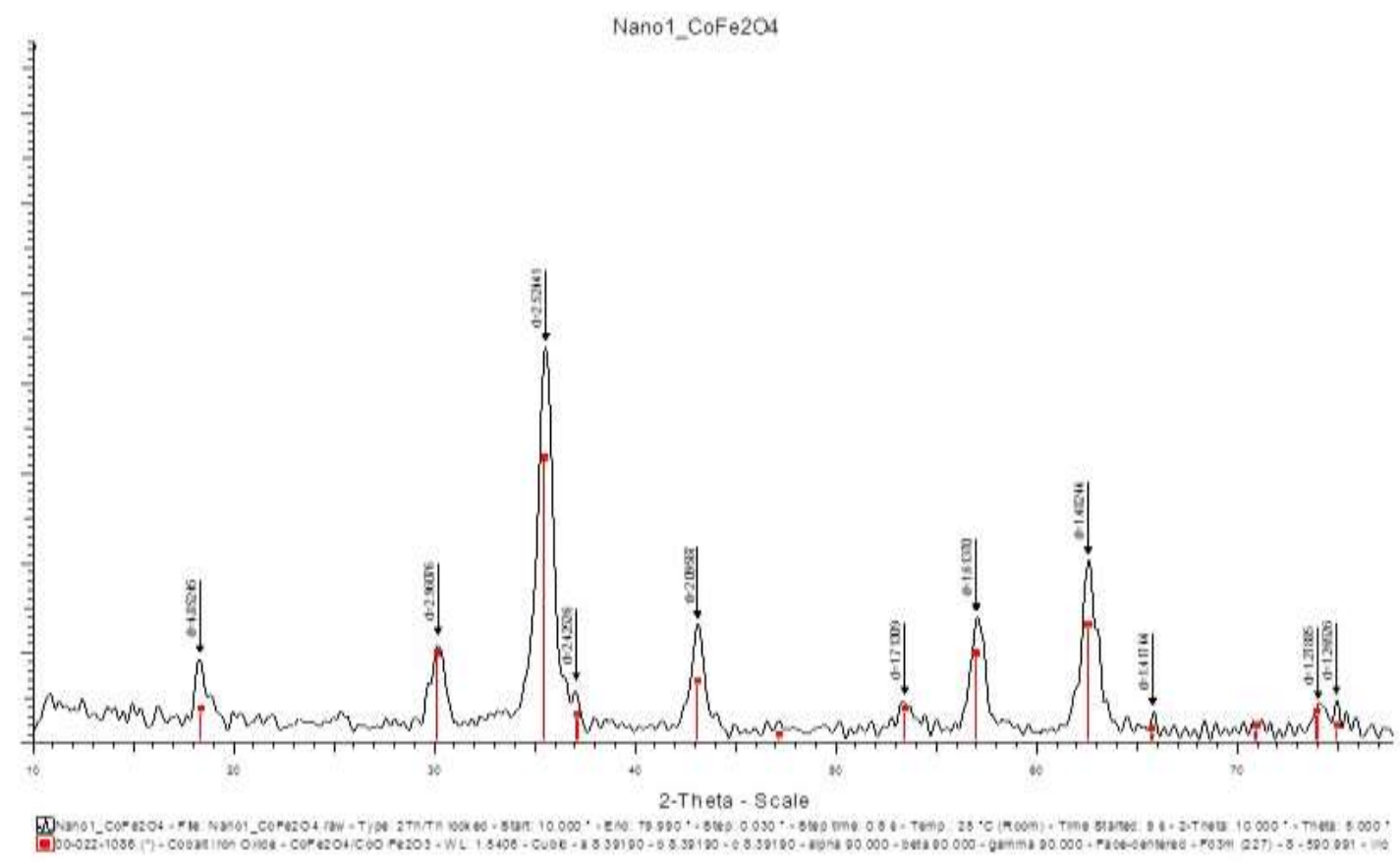

Figure 0.3. XRD pattern of $\mathrm{CoFe} 2 \mathrm{O} 4$ magnetic nanoparticles $(\mathrm{CuK} \alpha$ - radiation)

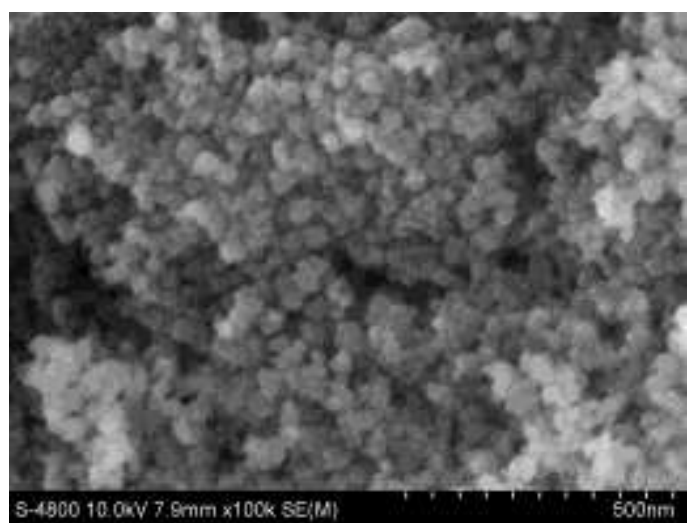

Figure 0.4. SEM image of $\mathrm{CoFe} 2 \mathrm{O} 4$ magnetic nanoparticles

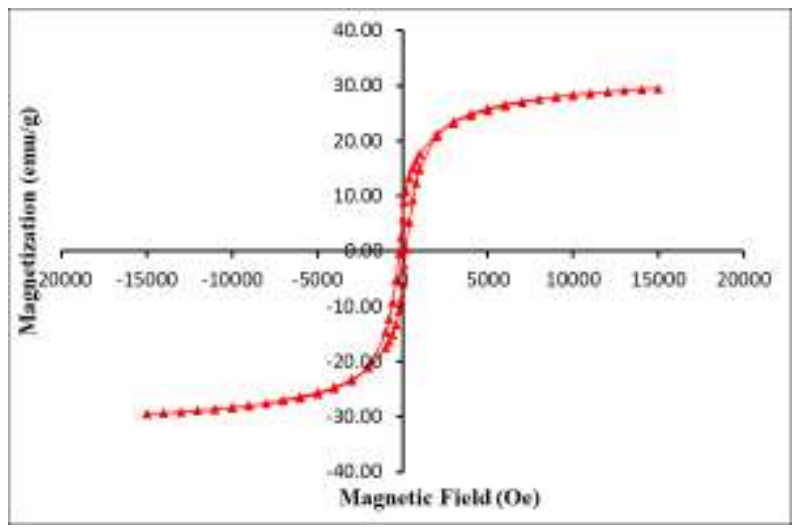

Figure 0.5. Hysteresis curve of $\mathrm{CoFe} 2 \mathrm{O} 4$ magnetic nanoparticles

In previous studies [21, 22], magnetic nanoparticles were dispersed in DMF solvent to investigate the magnetic properties at $305 \mathrm{~K}$. In the presence of an external magnetic field, the nanoparticles are magnetized with a saturated magnetization equals to that of a conventional magnetic material. However, unlike ordinary magnetic materials with residual magnetism, in the case of $\mathrm{CoFe}_{2} \mathrm{O}_{4}$ magnetic nanoparticles, when the external magnetic field reaches 0 , the magnetization of the sample is also suppressed. Due to this property, the magnetic nanoparticles are well dispersed in the solution, 
significantly increasing the contact surface area and also easily recovered, separated from the reaction mixture by an external magnetic field. The VSM results of $\mathrm{CoFe}_{2} \mathrm{O}_{4}$ particles are demonstrated in Figure 3.5 showing the saturation magnetization of $\mathrm{CoFe}_{2} \mathrm{O}_{4}$ particles is $29.48 \mathrm{emu} / \mathrm{g}$ and the corresponding coercivity is 399 Oe. The synthesized material has a relatively low coercivity which makes it as potential soft magnetic and superparamagnetic material, which is easily magnetized and easily demagnetized. With a saturation magnetization of $29.48 \mathrm{emu} / \mathrm{g}$ in combination with nanosize particles, the material has superparamagnetic properties and therefore the material disperses well in solution and is easily recovered by external magnetic field when applying for treatment of algae recovery.

\subsection{Synthesis and characterization of nanocomposite material}

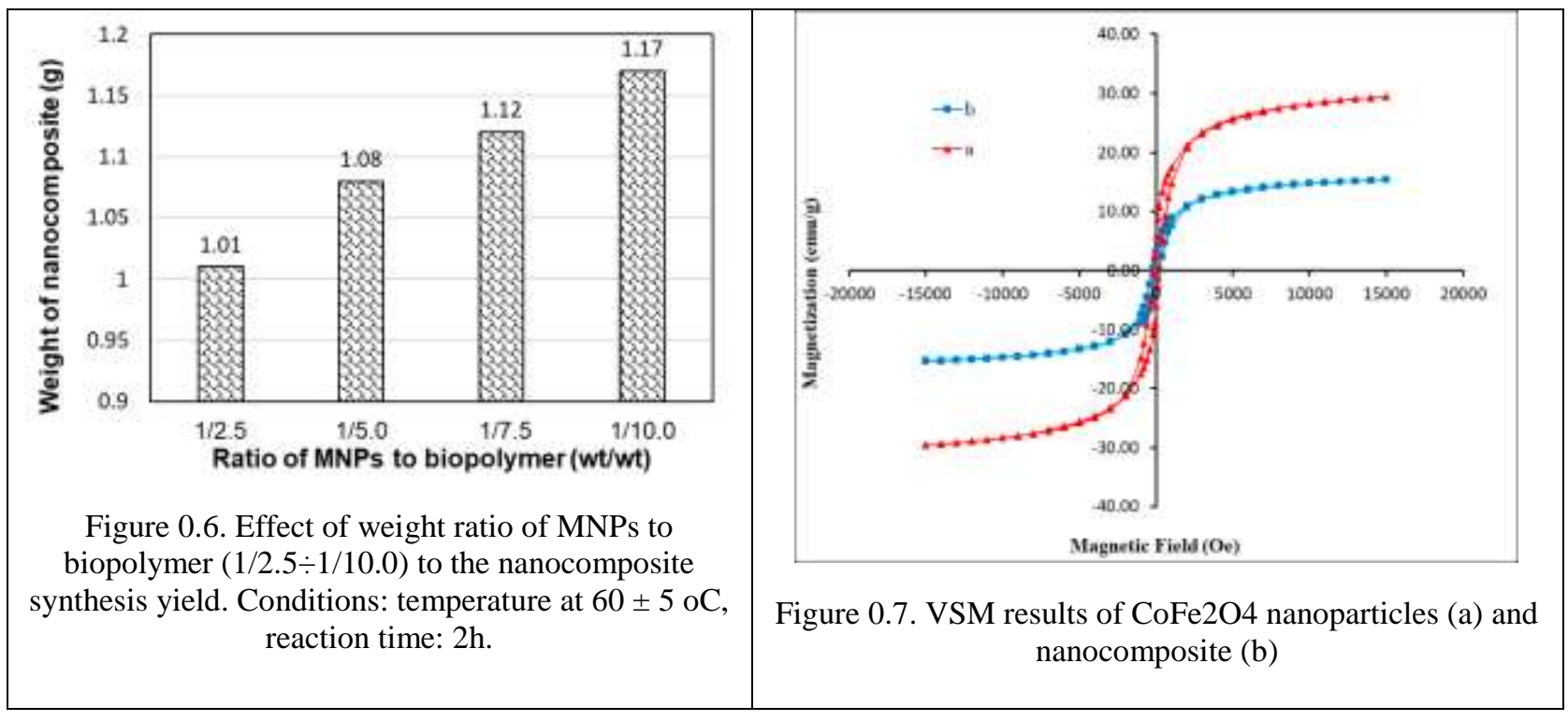

It is shown in Figure 3.6 that when the biopolymer mass increased (the ratio of magnetic nanoparticles/biopolymer decreased from $1 / 2.5$ to 1/10.0), the amount of achieved nanocomposite augmented. However, as the biopolymer mass increased further, the number of magnetic nanoparticles covered by biopolymer increases resulting in an increment of the obtained amount of nanocomposite. Despite this varied amount, the magnetization decreases due to the biopolymer magnetic resistance. VSM analysis results (Figure 3.7) show a very large difference in saturation magnetization between magnetic nanomaterials and nanocomposites, which is consistent with previous studies [23]. Even though the magnetic nanoparticles support the recovery process of nanocomposite (Figure 3.8), the synthesis of magnetic nanoparticles is expensive and produces many wastes. Therefore, $1 / 5$ was selected as the used ratio of magnetic nanoparticle/grapefruit peel biopolymer for others nanocomposite synthesis. 


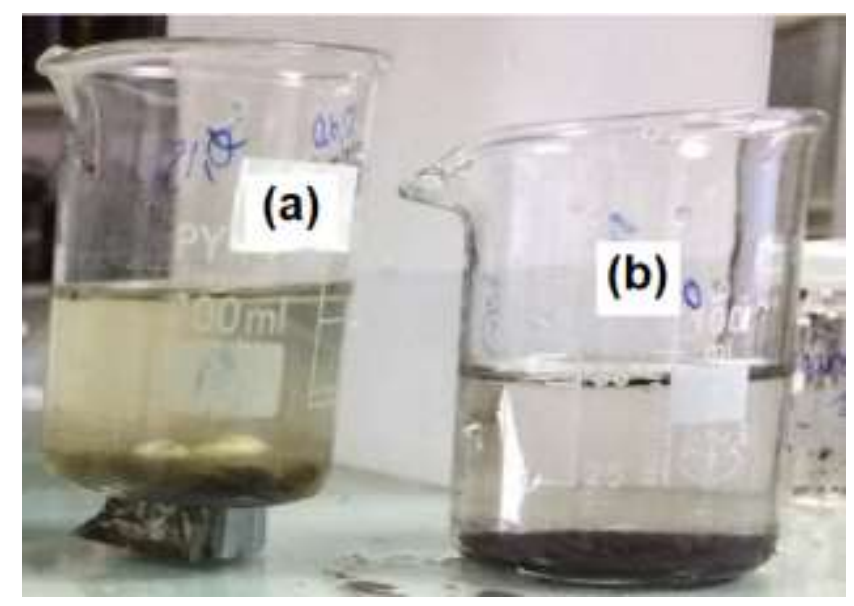

Figure 0 .8. Algae sample before (a) and after (b) algea recovery

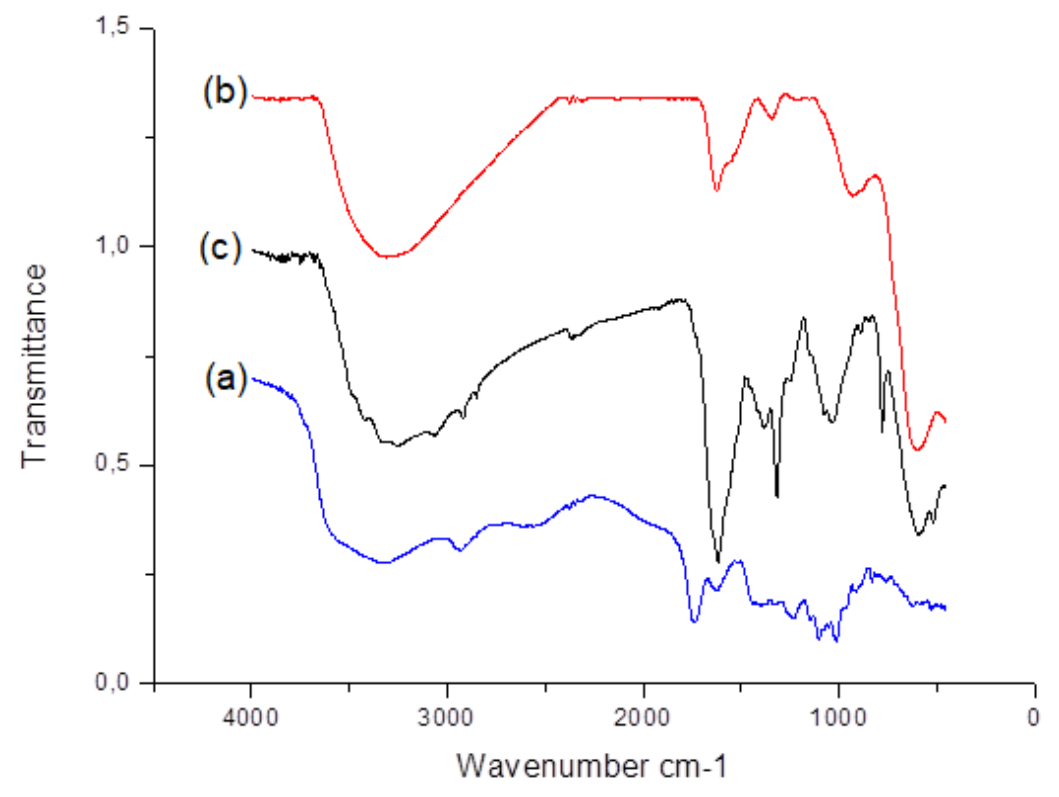

Figure 0.9. FT - IR spectra of grapefruit peel biopolymer (a), MNPs (b) and nanocomposite (c)

FT - IR analysis of the obtained biopolymer is demonstrated in Figure 3.9.a in which a strong vibration peak at the wavenumber of $3330.02 \mathrm{~cm}^{-1}$ was observed. This is the characteristic vibration of -OH group. Absorptions at $1729.65 \mathrm{~cm}^{-1}$ and $1428.2 \mathrm{~cm}^{-1}$ corresponding to the symmetric and asymmetric vibration bands, respectively signify the presence of $\mathrm{C}=\mathrm{O}$ bond in $\mathrm{COO}^{-}$group. In addition, the peaks at the wavenumber of $1239.53 \mathrm{~cm}^{-1}, 1102.5 \mathrm{~cm}^{-1}$ and $1016.87 \mathrm{~cm}^{-1}$ represent characteristic vibrations of $\mathrm{C}-\mathrm{O}$ in the C-O-H group of galactomannan [16, 24]. Nanocomposite material was also analysed by FT-IR (Figure 3.9.c) and the achieved spectrum shows the existence of valence vibration absorption of $\mathrm{Fe}-\mathrm{O}$ bond at the wavenumber of $604.2 \mathrm{~cm}^{-1}$, which is the characteristic vibration of $\mathrm{CoFe}_{2} \mathrm{O}_{4}$. The high intensity peak centered at $3424.6 \mathrm{~cm}^{-1}$ can be assigned to the characteristic vibration band of $-\mathrm{OH}$ group and the bands centered at $1621.4 \mathrm{~cm}^{-1}$ and $1417.5 \mathrm{~cm}^{-1}$ are associated to symmetric and asymmetric $\mathrm{C}=\mathrm{O}$ stretching vibrations in the $\mathrm{COO}^{-}$group, respectively $[16,24]$. According to previous reported works [23, 25-30], vibrations centered at $1621.4 \mathrm{~cm}^{-1}$ and $1417.5 \mathrm{~cm}^{-1}$ were also considered as symmetric and asymmetric metal-carboxylate bond $(\mathrm{COO}-\mathrm{Fe})$. The wavenumber separation $(\Delta)$ between the absorption bands $v_{\text {as }}(\mathrm{COO}-)$ and $v_{\mathrm{s}}(\mathrm{COO}-)$ can be used to classify interactions between terminal carboxylates and 
metal atoms. The $\Delta$ value $\left(1621.4-1417.5=203.9 \mathrm{~cm}^{-1}\right)$ can be referred to bidentate bridge between $\mathrm{COO}^{-}$anion group and $\mathrm{Fe}^{2+}, \mathrm{Fe}^{3+}[23,31,32]$.

\subsection{Recovery of Tetraselmis sp. using biopolymer, -OH enriched-magnetic nanoparticles and nanocomposite material}

\section{Effect of material composition and dosage on Tetraselmis sp. recovery efficiency}

In this study, the algae recovery consists of 3 stages including coagulation, flocculation and sedimentation. Figure 3.10 a shows results of comparing the algae Tetraselmis sp. recovery ability of biopolymer, magnetic nanoparticles enriched with $-\mathrm{OH}$ groups and nanocomposite materials under the same conditions in which the coagulation stage was carried out with stirring speed of $200 \mathrm{rpm}$ for 3 mins followed by flocculation with stirring slowly at $50 \mathrm{rpm}$ for 2 mins and finally, sedimentation was done with magnets for 30 minutes. It is clear that nanocomposite materials and $-\mathrm{OH}$ enriched magnetic nanoparticles yielded better recovery efficiency of algae Tetraselmis sp. than biopolymer. Additionally, the efficiency of collecting algae of grapefruit biopolymer is lowest. Therefore, in subsequent experiments, - $\mathrm{OH}$ enriched magnetic nanoparticles and nanocomposite materials were chosen for examining process conditions. Different dosages of both magnetic materials at 1.0, 2.0, 3.0, 4.0 and 5.0 $\mathrm{g} / \mathrm{L}$ were performed. As shown in Figure $3.10 \mathrm{~b}$, the harvesting efficiency increased strongly with increasing dosage of both magnetic materials and it reached more than $87 \%$ when the dosage was up to $4.0 \mathrm{~g} / \mathrm{L}$ for all materials. However, harvesting efficiency of algae Tetraselmis sp. showed a slight decrease when the dosage increased from 4.0 to $5 \mathrm{~g} / \mathrm{L}$. In comparison with other magnetic materials on microalgae harvesting, the magnetic separation by $\mathrm{CoFe}_{2} \mathrm{O}_{4}$ nanoparticles provided the harvesting efficiency in accordance with the finding by Seo et al [33], Zhu et al [34].
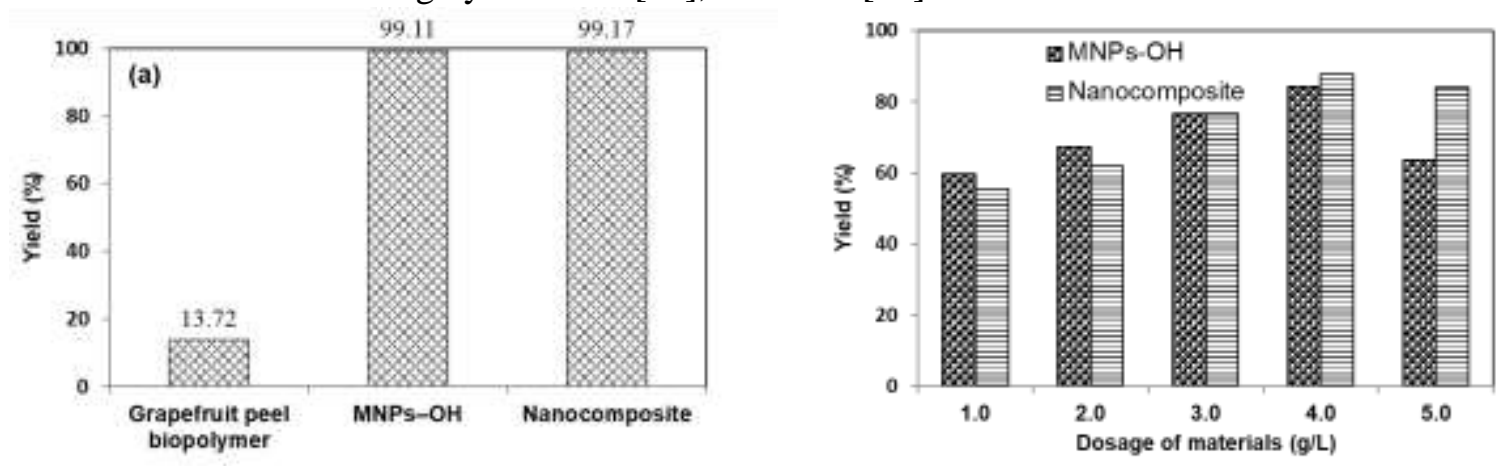

Figure 0.10. Effect of material composition (a) and dosage (b) on recovery efficiency with Tetraselmis sp. concentration: $4.275 .000(\mathrm{cell} / \mathrm{ml})$.

\section{Effect of coagulation parameters on the algae recovery ability of $-\mathrm{OH}$ enriched magnetic nanoparticles and nanocomposite materials}

To investigate the effect of coagulation parameters on the algae recovery ability, the experiments were performed for $0.2 \mathrm{~g}$ of $-\mathrm{OH}$ enriched magnetic nanoparticles or nanocomposite with the following conditions. Particularly, the coagulation was done with the stirring speed ranging from $100 \div 250 \mathrm{rpm}$ for $1 \div 4$ mins while the flocculation was carried out with the slow stirring of $50 \mathrm{rpm}$ for 2 mins. Then, magnetic sedimentation lasted for 30 mins. Stirring is essential for the initial coagulation to favor the interaction between the coagulants and microalgae which is advantageous for a good coagulation leading to the formation of colloidal floc. However, if the slow stirring speed is not sufficient for creating good contact of microalgae with coagulants. On the other hand, if the stirring speed is too fast, the formed colloidal floc will be broken leading to the deduction in the efficiency of algae recovery. As the stirring speed increases, the recovery of algae increases. Neverthless, continuing to increase the stirring speed up to $250 \mathrm{rpm}$ caused an insignificant decrease in the efficiency of algae recovery for both coagulants (Figure $3.11 \mathrm{a}$ ). Regarding the effect of stirring time, the algae recovery efficiency increased when augmenting the time, reaching the highest efficiency at 3 minutes. Further increasing the stirring time to 4 
minutes resulted in the degradation of the efficiency (Figure $3.11 \mathrm{~b}$ ). Clearly, at this coagulation stage, initially quick stirring is necessary to promote the contact between coagulants and microalgae and the longer it takes, the more effective this exposure will be. However, it should be noted that quick stirring for a long time will cause the disruption of the colloidal flocs, hence reducing the recovery efficiency of algae. It was also reported in other researches that stirring time and speed in the coagulation stage were dependent on the type of coagulants and type of algae [7,35-37].
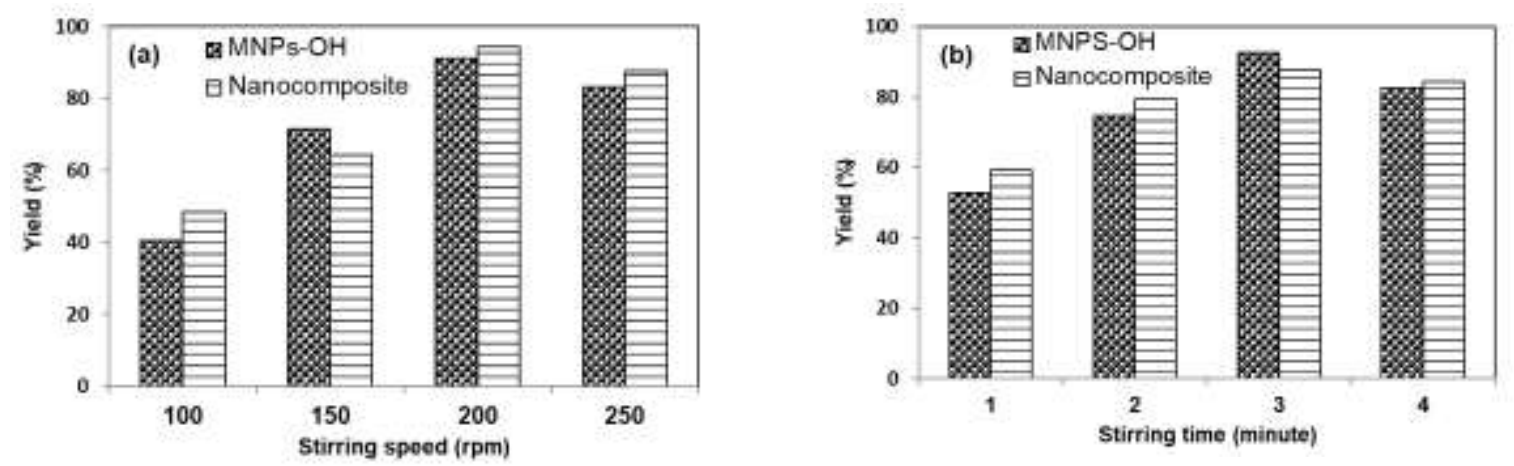

Figure 0.11. Effect of stirring speed (a) and stirring time (b) in the coagulation stage for both magnetic nanomaterials. In which, Algae Tetraselmis sp. concentration: (a) 4.500 .000 (cells/ml); (b) 4.350 .000 (cells/ml)

\section{Effect of flocculation parameters on the algae recovery ability of $-\mathrm{OH}$ enriched magnetic nanoparticles and nanocomposite materials}

To investigate the effect of flocculation parameters on the algae recovery ability, the experiments were also performed for $0.2 \mathrm{~g}$ of $-\mathrm{OH}$ enriched magnetic nanoparticles or nanocomposite with the following conditions. Particularly, the coagulation was done with the stirring speed of $200 \mathrm{rpm}$ for 3 mins as determined in the above results while the flocculation was carried out with the slow stirring ranging $30 \div 60 \mathrm{rpm}$ for $1 \div 4 \mathrm{mins}$. Then, magnetic sedimentation lasted for $30 \mathrm{mins}$. The results showed that when the flocculation stirring speed raises, the efficiency of algae recovery increases. In addition, it can be seen thatthe highest efficiency was reached at $50 \mathrm{rpm}$ and declines at of the speed of upto $60 \mathrm{rpm}$ (Figure 3.12 a). It could be assumed that high stirring speed leads to the break of colloidal flocs, hence reducing their linking capability. As a result, the microalgae disperse back into the aqueous environment and the algae recovery efficiency decreases. On the other hand, the introduced coagulants would not spread evenly if the stirring speed is slow. This would cause ineffective collision and contact of the colloidal particles which also makes the algae recovery efficiency decrease. It is noted that when increasing the flocculation stirring time from 1 minute to 2 minutes, the highest algae recovery efficiency was achieved. However, further increasing the stirring time resulted in the decreased efficiency of algae recovery (Figure $3.12 \mathrm{~b}$ ). This might due to the fact that during the flocculation, the colloidal flocs will be broken with long stirring time and this reduces the ability to create the bridge among the flocs. On the other hand, short stirring time is not sufficient for the coagulants to be distributed inevenly. Similarly, the collision and contact of the colloidal particles are limited and the algae recovery efficiency would also decrease [35, 37-41]. 

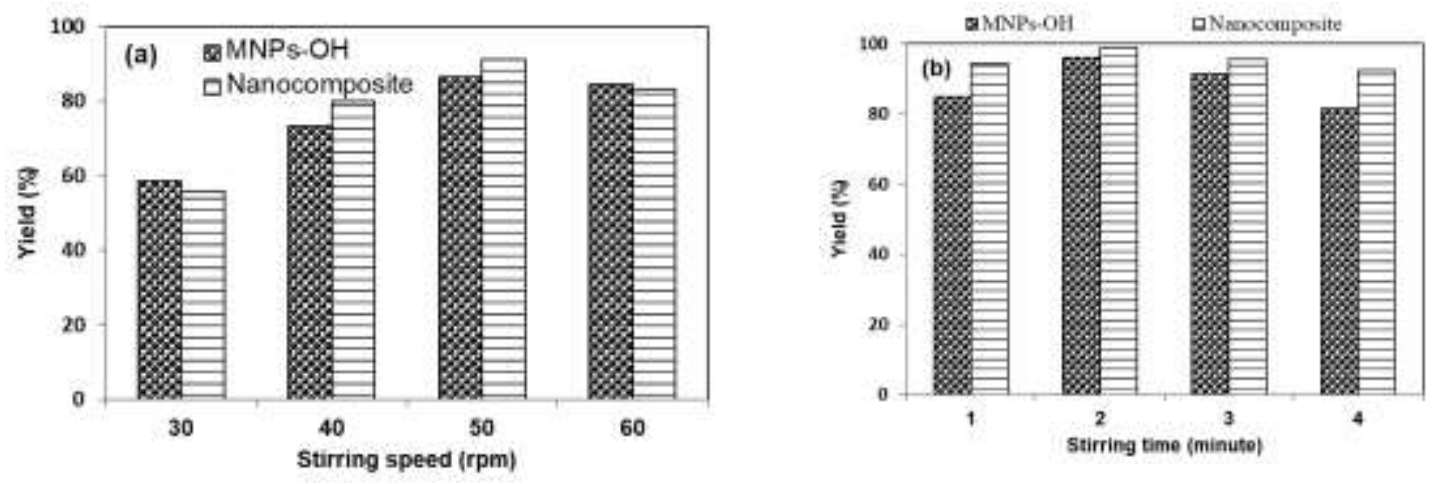

Figure 0.12. Effect of stirring speed (a) and stirring time (b) in the flocculation stage for both magnetic nanomaterials. In which, Algae Tetraselmis sp. concentration: (a) 3.750 .000 (cells/ml); (b) 4.600.000 (cells/ml).

\section{CONCLUSIONS}

The results show that the highest yield of the biopolymer isolation from grapefruit peel was obtained with sample/solvent ratio of $30 / 1$ and citric acid concentration of $10 \mathrm{wt} \%$ at $85{ }^{\circ} \mathrm{C}$ in 130 mins. The $30-40 \mathrm{~nm}$ $\mathrm{CoFe}_{2} \mathrm{O}_{4}$ nanomaterial was synthesized successfully which was confirmed with XRD. XRD results were consistent with standard data showing the "cubic spinel" structure. The superparamagnetic nanocomposites were also productively achieved by incorporating $\mathrm{CoFe}_{2} \mathrm{O}_{4}$ magnetic nanoparticles into grapefruit peel biopolymer matrix. The obtained magnetic nanoparticles and nanocomposites were efficiently utilized for algae harvesting and the optimum process conditions to get highest collecting yield were also investigated and recorded. These findings in this study provide new opportunities and challenges for understanding and improving microalgal biomass harvesting with the assistance of magnetic nanomaterials. Additionally, the results also show high potent of using agricultural waste like grapefruit peel for synthesizing nanocomposites for various applications. This contributes to the reduction of disposed waste and helps to protect the environment.

\section{ACKNOWLEDGMENT}

The authors wish to thank Assoc. Prof. Dr. Le Hung Anh, Dean of Institute of Environmental Science, Engineering and Management (IESEM), Industrial University of Hochiminh City (IUH) for his microalgae supply.

\section{REFERENCES}

[1] Grégorio Crini and Eric Lichtfouse, "Advantages and disadvantages of techniques used for wastewater treatment," Environmental Chemistry Letters, vol. 17, pp. 145-155, 2019.

[2] Cynthia Alcantara et al., "Microalgae-based Wastewater Treatment," Biotechnology Advances, vol. 215, pp. 439-455, 2015.

[3] Andrew Pratt, "Environmental Applications of Magnetic Nanoparticles," Frontiers of Nanoscience, vol. 6, pp. 259-307, 2014.

[4] Guixia Zhao et al., "Polymer-based nanocomposites for heavy metal ions removal from aqueous solution: a review," Polymer Chemistry, vol. 9, pp. 3562-3582, 2018.

[5] Ammar Ahmad Khan et al., "Extraction and characterization of pectin from grapefruit (Duncan cultivar) and its utilization as gelling agent," International Food Research Journal, vol. 21, pp. 2195-2199, 2014. 
[6] Mohamed S. A. Darwish et al., "Synthesis of Magnetic Ferrite Nanoparticles with High Hyperthermia Performance via a Controlled Co-Precipitation Method," Nanomaterials vol. 9, pp. 1176 - 1196, 2019.

[7] Jose A.Gerde et al., "Microalgae flocculation: Impact of flocculant type, algae species and cell concentration," Algal Research, vol. 3, pp. 30-35, 2014.

[8] K. Gazala et al.,, "Extraction and characterisation of pectin from two apple juice concentrate processing plants," International Food Research Journal, vol. 24, pp. 594-599, 2017.

[9] Søren Vodstrup Jensen et al., Process for extraction of pectin, US Patent 20120309946 (A1), 2011.

[10] Maazullah Khan et al., "Optimization of Process Conditions for Pectin Extraction from Citrus Peel," Science, Technology and Development vol. 34, pp. 9-15, 2015.

[11] Francisco M. Goycoolea and Adriana Cárdenas, "Pectins from Opuntia spp.: A Short Review," Journal of the Professional Association for Cactus Development, vol. 5, pp. 17-29, 2003.

[12] Salam M. A. et.al., "Extraction of Pectin from lemon peel: Technology development," Journal of Chemical Engineering, vol. ChE 27, pp. 25-30, 2012.

[13] Merve Kaya et al., "Characterization of citrus pectin samples extracted under different conditions: influence of acid type and pH of extraction," Annals of Botany, vol. 114, pp. 1319-1326, 2014.

[14] D.DJoye and G.ALuzio, "Process for selective extraction of pectins from plant material by differential $\mathrm{pH}$," Carbohydrate Polymers, vol. 43, pp. 337 - 342, 2000.

[15] Huda Mohamed, "Extraction and characterization of pectin from grapefruit peels," MOJ Food Processing \& Technology, vol. 2, p. 31-38, 2016.

[16] Adriana Cárdenas et al., "On the gelling behaviour of "nopal' (Opuntia ficus indica) low methoxyl pectin," Carbohydrate Polymers, vol. 73, pp. 212-222, 2008.

[17] M. Vadivel et al., "Role of SDS surfactant concentrations on the structural, morphological, dielectric and magnetic properties of CoFe2O4 nanoparticles," The Royal Society of Chemistry, vol. 5, pp. 27060-27068 2015.

[18] Hoàng Thị Tuyết và Nguyễn Anh Tiến, "Tổng hợp, cấu trúc và từ tính của vật liệu nano $\mathrm{CoFe} 2 \mathrm{O} 4$ bằng phương pháp đồng kết tủa," Tạp chí Hóa học, vol. 53, pp. 441 - 444, 2015.

[19] Yeong Il Kim et al., "Synthesis and characterization of $\mathrm{CoFe} 2 \mathrm{O} 4$ magnetic nanoparticles prepared by temperature-controlled coprecipitation method," Physica B: Condensed Matter, vol. 337, pp. 42 - 51, 2003.

[20] Anna Zielińska-Jurek, Joanna Reszczyńska, Ewelina Grabowska and Adriana Zaleska (2012). Nanoparticles Preparation Using Microemulsion Systems, Microemulsions - An Introduction to Properties and Applications, Dr. Reza Najjar (Ed.), ISBN: 978-953-51-0247-2, InTech, Available from:

http://www.intechopen.com/books/microemulsions-an-introduction-to-properties-andapplications/nanoparticlespreparation-using-microemulsion-systems

[21] X. Xu-xian et al., "Synthesis and characterization of CoFe2O4 nanoparticles," Trans. Nonferrous Met. Soc. China, vol. 15, pp. 1072 - 1077, 2005.

[22] K. Can et al., "Immobilization of albumin on aminosilane modified superparamagnetic magnetite nanoparticles and its characterization," Colloids and Surfaces B: Biointerfaces, vol. 71, pp. 154-159, 2009.

[23] Jude Namanga et al., "Synthesis and Magnetic Properties of a Superparamagnetic Nanocomposite "PectinMagnetite Nanocomposite"," Journal of Nanomaterials, p. 8, 2013. 
[24] B. Kazemzadeh et al., "Synthesis of a Novel Pectin-Based Superabsorbent Hydrogel with Salt and pHResponsiveness Properties," Biomed. \& Pharmacol. J., vol. 6, pp. 41 - 48, 2013.

[25] H. Iida et al., "Synthesis of Fe3O4 nanoparticles with various sizes and magnetic properties by controlled hydrolysis," Journal of Colloid and Interface Science, vol. 314, pp. 274-280, 2007.

[26] S. Sahu and R. K. Dutta, "Novel hybrid nanostructured materials of magnetite nanoparticles and pectin," Journal of Magnetism and Magnetic Materials, vol. 323, pp. 980-987, 2011.

[27] J. Dai et al., "Facile synthesis of pectin coated Fe3O4 nanospheres by the sonochemical method," Journal of Magnetism and Magnetic Materials, vol. 331, pp. 62 - 66, 2013.

[28] Ji-Lai Gong et al., "Copper (II) removal by pectin-iron oxide magnetic nanocomposite adsorbent," Chemical Engineering Journal, vol. 185 - 186 pp. 100 - 107, 2012.

[29] D. Predoi et al., "Synthesis and characterization of bio-compatible maghemite nanoparticles," Digest Journal of Nanomaterials and Biostructures, vol. 5, pp. 779-786, 2010.

[30] A. Rampino et al., "Chitosan-pectin hybrid nanoparticles prepared by coating and blending techniques," European Journal of Pharmaceutical Sciences, vol. 84, pp. 37-45, 2016.

[31] L. Guo et al., "Preparation and characterization of chitosan poly(acrylic acid) magnetic microspheres," Marine Drugs, vol. 8, pp. 2212-2222, 2010.

[32] K. S.Wilson et al., "A generalized method for magnetite nanoparticle steric stabilization utilizing block copolymers containing carboxylic acids," European Cells and Materials, vol. 3, pp. 206 - 209, 2002.

[33] Jung Yoon Seo et.al., "Tri-functionality of Fe3O4-embedded carbon microparticles in microalgae harvesting," Chemical Engineering Journal, vol. 280, pp. 206-214, 2015.

[34] L.D. Zhu et al., "Using magnetic materials to harvest microalgal biomass: evaluation of harvesting and detachment efficiency," Environmental Technology, vol. 40, pp. 1006-1012, 2019.

[35] Naruetsawan Sanyano et al., "Coagulation-flocculation of marine Chlorella sp. for biodiesel production," Bioresource Technology vol. 147, pp. 471-476, 2013.

[36] Pey Yi Toh et al., "The Role of Cationic Coagulant-to-Cell Interaction in Dictating the Flocculation-Aided Sedimentation of Freshwater Microalgae," Arabian Journal for Science and Engineering, vol. 43, pp. 2217-2225, 2018.

[37] Chengrong Peng et al., "Harvesting Microalgae with Different Sources of Starch-Based Cationic Flocculants," Appl Biochem Biotechnology, vol. 181, pp. 112-124, 2017.

[38] Carlos Octavio Letelier-Gordo et al, "Effective harvesting of the microalgae Chlorella protothecoides via bioflocculation with cationic starch," Bioresource Technology, vol. 167C, pp. 214-218, 2014.

[39] Martin Cerff et al., "Harvesting fresh water and marine algae by magnetic separation: Screening of separation parameters and high gradient magnetic filtration," Bioresource Technology, vol. 118, pp. 289-295, 2012

[40] Yi-Ru Hu et al., "Efficient harvesting of marine microalgae Nannochloropsis maritima using magnetic nanoparticles," Bioresource Technology vol. 138, pp. 387-390, 2013.

[41] Dries Vandamme et al., "Flocculation of microalgae using cationic starch," Journal of Applied Phycology, vol. 22, pp. 525-530 2010. 


\section{GIẢI PHÁP THU GOM VI TẢO TRONG XỦ̉ LÝ NƯỚC SỦ̉ DỤNG VẠT LIÊUU NANO TỪ TÍNH NGUỒN GỐC BIOPOLYMER CHIẾT XUẤT TÙ VỎ BƯởI}

Tóm tắt. Trong nghiên cứu này, vật liệu nanocomposite từ tính đã được tạo ra bằng cách kết hợp các hạt nano coban siêu thuận từ $\left(\mathrm{CoFe}_{2} \mathrm{O}_{4}\right)$ vào ma trận polymer sinh học được chiết xuất từ vỏ bưởi. Trong đó, các hạt nano từ tính được điều chế bằng phương pháp đồng kết tủa và sự hình thành nanocomposite được thực hiện với sự hỗ trợ của sóng siêu âm. Các polymer sinh học, hạt nano và nanocomposite được phân tích bởi phương pháp quang phổ hồng ngoại biến đổi Fourier (FT-IR) trong khi các hạt nano và nanocomposite được phân tích thêm bằng nhiễu xạ tia $\mathrm{X}(\mathrm{XRD})$, kính hiển vi điện tử quét $(\mathrm{SEM})$ và từ kế mẫu rung (VSM). Cuối cùng, khả năng thu hồi vi tảo Tetraselmis sp. sử dụng các nanocomposite thu được và ảnh hưởng của các yếu tố khác nhau bao gồm khối lượng vật liệu, tốc độ khuấy và thời gian khuấy lên hiệu suất thu hồi cũng đã được nghiên cứu.

Từ khóa. nanocomposite, từ tính, bưởi, polymer sinh học, vi tảo. 